\title{
INSTRUCTION TO CONTRIBUTORS
}

The Journal of Helminthology publishes papers on all aspects of animal parasitic helminths, particularly those of medical or veterinary importance, but only in exceptional circumstances will systematic or taxonomic studies be acceptable.

Manuscripts, which must be in English or French (with an English summary) should be accompanied by a letter signed by all the authors and should be addressed to:

The Editor, Journal of Helminthology,

London School of Hygiene and Tropical Medicine,

Winches Farm Field Station,

395 Hatfield Road,

St Albans, Herts AL4 OXQ,

England.

Two copies of a typescript, on size A4 paper with double spacing, should be submitted. Papers should be preceded by a short abstract and will normally have the following sections: brief Introduction; Materials and Methods; Results; Discussion; Acknowledgements; References. However, the form of the paper may vary, depending on its subject matter; recent past issues should be consulted for a suitable form. Research Notes should also be preceded by a brief abstract. Illustrations should be drawn in Indian ink, preferably not more than double the final size. Care should be taken that all illustrations fit into the format of the Journal. The maximum size an illustration will be printed is $12.0 \times 20.0 \mathrm{~cm}$. Where many separate drawings are made, some indication of how they may be grouped to make a corporate plate without undue wastage of space, should be indicated. Some indication of scale (preferably a scale bar) should normally be given on the figure. Photocopies of illustrations should be enclosed for refereeing purposes. Lettering and numbering, which must be of a high standard, should be added by the author, with due regard for subsequent reduction.

Photographs should be glossy prints of the same size as they are to appear in the Journal (maximum size $12.0 \times 20.0 \mathrm{~cm}$ ). Composite prints must be mounted and can have the separate photographs abutting; they will then have a separating line inserted by the printers. All figures and letters on photographs must be inserted by the author.

Information should not be repeated in the text and in tables or figures. The legends to tables and to figures should be sufficiently detailed for the information to be understood without reference to the text.

References should be given in alphabetical order with the full title of the journal. The following are examples:

DUKE, B. O. L. (1971) The ecology of onchocerciasis in man and animals. In: Ecology' and Physiology of parasites (editor, A. M. Fallis) pp. 213-222. Adam Hilger Ltd.: London.

JAMES, C.\& WEBBE, G.(1973) A comparison of Egyptian and East African strains of Schistosoma haematobium. Journal of Helminthology, 47, 49-59.

25 offprints are provided free of charge; additional copies may be ordered at the proof stage. 


\section{Contents}

Efficacy of UV-irradiated larval vaccine of Ancylostoma ceylanicum (Looss, 1911) in golden hamsters (Mesocricetus auratus). S. MENON and M. K. BHOPALE

The cercaria and metacercaria of Galactosomum ussuriense Oshmarin, 1963 (Trematoda: Heterophyidae). Z. REKHARANI and R. MADHAVI

arvicidal effect of flubendazole on Angiostrongylus cantonensis in mice with various

\begin{tabular}{l} 
Larvicidal effect of flubendazole on Angiostrongylus cantonensis in mice with various \\
worm burdens. J. MAKI and T. YANAGISAWA \\
\hline
\end{tabular}

Experimental infection of pups with Ancylostoma caninum larvae from an abnormal host, the chicken. S. MITTRA and N. K. SASMAL

The efficacy of some newer broad spectrum anthelmintics against third-stage larvae of Ancylostoma caninum in the mouse. G. M. BHOPALE and B. S. BHATNAGAR

Comparison of the protective resistance induced by ${ }^{\circ} \mathrm{Co}$-irradiated cercariae and schistosomula of the WFFS and NMRI strains of Schistosoma mansoni. E. R. JAMES and A. R. DOBINSON

Pancreatic secretion is the migratory cue for Hymenolepis diminuta in the rat small intestine. C. H. CHO

Enzyme analyses of natural populations of Schistocephalus solidus and Ligula intestinalis. D. P. McMANUS

Impairment of primary expulsion of Echinostoma revolutum in mice concurrently infected with Schistosoma mansoni. (Research Note). N. Ø. CHRISTENSEN, J. KNUDSEN, B. FAGBEMI and P. NANSEN

Immunity to Onchocerca lienalis microfilariae in mice. II. Effects of sensitization with a range of heterologous species. S. TOWNSON, G. S. NELSON and A. E. BIANCO

Unusual protein pattern of Opisthorchis viverrini. (Research Note). A. RUPPEL, S. BOONPUCKNAVIG and E. HEMPELMANN

Studies on the abomasal pathology of immunized and non-immunized sheep infected with Haemonchus contortus. S. K. SALMAN and J. L. DUNCAN

Adult worms of a 'Dipetalonema' sp. from the dermis of cattle in the Sudan. (Research Note). M. B. MUSTAFA, L. F. KHALIL and A. E. BIANCO

Announcements $294,312,318,360$

Corrigenda

Subject Index

Author Index 